\title{
PREVENTIVE AND CURATIVE CONTROL OF Oidium eucalypti IN Eucalyptus benthamii CLONAL SEEDLINGS ${ }^{1}$
}

\author{
Marcieli Pitorini Bovolini2 ${ }^{*}$, Marília Lazarotto ${ }^{3}$, Mateus Pereira Gonzatto $^{3}$, Larissa Campos de Sá $^{3}$ and
} Norton Borges Junior ${ }^{4}$

\footnotetext{
${ }^{1}$ Received on 16.03.2018 accepted for publication on 04.10.2018.

${ }^{2}$ Universidade Federal do Rio Grande do Sul, Programa de Pós-Graduação em Fitotecnia, Porto Alegre, RS-Brasil. E-mail: $<$ m.p.b.engenhariaf@gmail.com>.

${ }^{3}$ Universidade Federal do Rio Grande do Sul, Faculdade de Agronomia, Porto Alegre, RS-Brasil. E-mail: <lilalazarotto@yahoo.com.br>, $<$ mpgonzatto@gmail.com $>$ and $<$ desa_larissa@hotmail.com $>$.

${ }^{4}$ CMPC Celulose Riograndense, Guaiba, RS-Brasil. E-mail: <norton.borges@cmpcrs.com.br>.

*Corresponding author.
}

\begin{abstract}
One of the main diseases occurring in clonal nurseries of Eucalyptus spp. is powdery mildew caused by the fungus Oidium eucalypti. This work evaluated the efficiency of biological products based on Trichoderma spp. and Bacillus spp. applied as preventive and curative treatments for the control of Oidium eucalypti in clonal seedlings of E. benthamii Maiden et Cambage. Treatments were: Trichoderma harzianum (THP), T. atroviride (TAI), T. harzianum (THE), Trichoderma spp. (TTA), Bacillus spp. (BNE), Sulfur (KUM), Difenoconazol (SCO) and distilled water (AD). Treatments were applied preventively by spraying seven days before inoculation of the pathogen, and in curatively, ten days after inoculation. Weekly evaluations of the incidence and severity of the disease were done. The analyzed variables were: Disease Index (ID) and Incidence (I), calculating the area under the disease curve (AUDPC) for each treatment. The results pointed BNE (Bacillus spp.) and TAI (isolate T. atroviride) as effective preventive treatments and BNE (Bacillus spp.), applied curatively for the control of $O$. eucalypti in E. benthamii seedlings, proving that treatments based on biological products may be effective for controlling eucalyptus powdery mildew in clonal nurseries.
\end{abstract}

Keywords: Bacillus spp.; Forest production; Powdery Mildew.

\section{CONTROLE PREVENTIVO E CURATIVO DE Oidium eucalypti EM MUDAS CLONAIS DE Eucalyptus benthamii}

\begin{abstract}
RESUMO - Uma das principais doenças que ocorrem nos viveiros clonais de Eucalyptus spp. é o oídio causado pelo fungo Oidium eucalypti. O objetivo deste trabalho foi avaliar a eficiência de produtos biológicos baseados em Trichoderma spp. e Bacillus spp. aplicados na forma de tratamentos preventivos e curativos para o controle de O. eucalypti em mudas clonais de E. benthamii Maiden et Cambage. Os tratamentos foram: Trichoderma harzianum (THP), T. atroviride (TAI), T. harzianum (THE), Trichoderma spp. (TTA), Bacillus spp. (BNE), Enxofre (KUM), Difenoconazol (SCO) e água destilada (AD). Estes foram aplicados preventivamente por pulverização sete dias antes da inoculação do patógeno, e, de forma curativa, dez dias após a inoculação. Foram realizadas avaliações semanais da incidência e severidade da doença. As variáveis analisadas foram: Índice de Doença (ID) e Incidência (I), calculando-se a área abaixo da curva de progresso da doença (AACPD) para cada tratamento. Os resultados evidenciaram BNE (Bacillus spp.) e TAI (T. atroviride isolado) como efetivos quando aplicados preventivamente, e o tratamento BNE (Bacillus spp.) também efetivo em aplicação curativa para o controle biológico de O. eucalypti em mudas clonais de E. benthamii, comprovando-se que tratamentos baseados em produtos biológicos podem ser eficazes para controlar o oídio no eucalipto nos viveiros clonais.
\end{abstract}

Palavras-Chave: Bacillus spp.; Produçãoflorestal; Oídio. 


\section{INTRODUCTION}

Eucalypt plantation in Brazil is intensive, and, in the state of Rio Grande do Sul, it has occupied significant areas of production. The plantations are established mainly with cuttings from selected mother trees, using criteria that express high productivity. According to a report by the Indústria Brasileira de Árvores (IBÁ, 2017), the total area planted with trees was 7.84 million ha in 2016, a growth of $0.8 \%$ in relation to the previous year. The report also states that eucalypt plantations occupy 5.6 million ha in the country and, in the last five years, the growth of the eucalypt area was $2.8 \%$ per year.

Among the species planted in the country, Eucalyptus benthamii Maiden et Cambage presents as peculiar characteristics its resistance to frost, good stem shape, rusticity and fast growth, predominating in clonal forest plantations in southern Brazil. Its characteristics intensified the demand for seedlings, demanding for in-depth studies on aspects relevant to the species production in nursery conditions (Schultz, 2011). During the production of eucalypt seedlings in nurseries, pathogen attacks are frequent, especially those caused by fungi, which reduce the production of seedlings, causing economic losses, depending on the species attacked, time of the year (Santos et al., 2001 ) and the stage of seedling development.

One of the main diseases causing damage in $E$. benthamii clonal mini gardens is powdery mildew, caused by the fungus Oidium eucalypti. This pathogen has greater incidence in young leaves and shoots, occurring mainly in greenhouse and clonal mini garden, causing distorted leafs and over-sprouting of the plants, causing, in more severe cases, death of the seedlings (Krugner and Auer, 2005). Due to the high conidia dissemination capacity, this fungus rapidly infects healthy ministumps, causing infestation throughout the clonal mini garden.

The fungicide Priori Top ${ }^{\circ}$, composed of azoxystrobin and difenoconazole, was recently registered in the Ministry of Agriculture, Livestock and Supply for the control of $O$. eucalypti in eucalypt plantation. However, according to Campanhola and Bettiol (2003), alternatives have already been proposed with cultural control, genetic and natural products. Thus, other forms of control can also be used, alternatively or in joint use, since the best way to maintain a controlled pathogen population is the combination of techniques, namely integrated management.

\footnotetext{
Revista Árvore. 2018;42(5):e420504
}

An alternative to chemical control, for example, is the use of biological control agents such as Trichoderma spp. and Bacillus spp., which have been recommended as potential biocontrollers of several plant pathogens, especially in the last decades. The capacity of Trichoderma spp. of acting as a biocontrol agent has been reported for more than 60 years, and many isolates are classified as plant symbionts and actuators in the control of phytopathogens (Brotman et al., 2010).

The species of the Trichoderma genus are among the most studied antagonists and are found naturally in different types of soil. They act against phytopathogens by different mechanisms, such as: antibiosis, nutrient and substrate competition, mycoparasitism, cell wall degrading enzymes production, plant growth promotion and resistance inducers (Harman et al., 2004; Shoresh et al., 2005; Viterbo et al., 2005; Vinale et al., 2008). Trichoderma spp. are used to control important diseases such as those caused by Botrytis cinerea (Sanz et al., 2005), Rhizoctonia solani (Ruocco et al., 2009), Pythium ultimum (Montero et al., 2011), Fusarium oxysporum (Carvalho et al., 2011) and Moniliophthora perniciosa (Simões et al., 2012).

Bacillus species are antagonists of phytopathogenic fungi and can be used in biological control (Angonese et al., 2009). According to Bettiol and Morandi (2009), within the genus Bacillus, the species Bacillus subtilis and B. pumilus are able to inhibit phytopathogenic bacteria and fungi. Bacillus spp. have the ability to control diseases caused by Fusarium moniliforme (Bacon et al., 2001), Colletotrichum acutatum (Kupper et al., 2003), Erwinia carotovora (Dong et al., 2004), Botrytis cinerea (Hang et al., 2005) and Puccinia psidii (Raasch et al., 2012), which cause great damage to the affected crops.

The objective of this work was to evaluate the efficiency of biological products based on Trichoderma spp. and Bacillus spp. applied preventively and curatively to control Oidium eucalypti in tree cuttings of $E$. benthamii.

\section{MATERIALAND METHODS}

\subsection{Place of experiments, seedlings origin and inoculum}

The experiments were done from January to March of 2016 in a greenhouse belonging to the Laboratory 
of Plant Bacteriology of the Plant Protection Department of the Federal University of Rio Grande do Sul (UFRGS), in Porto Alegre, RS.

Cuttings of Eucalyptus benthamii with approximately 90 days old were provided by CMPC - Celulose Riograndense nursery's company, located in Barra do Ribeiro, RS (Geographical coordinates: $30^{\circ} 20^{\prime} 38.3^{\prime \prime} \mathrm{S} 51^{\circ} 14^{\prime} 43.9^{\prime \prime} \mathrm{O}$ ). The seedlings were immediately brought to the greenhouse, where they were put in trays with $50 \mathrm{~cm}^{3}$ containers and maintained with daily manual irrigation, moistening only the substrate during the experiment.

The Oidium eucalypti isolate was obtained from the clonal mini garden, a natural source of the pathogen occurrence, belonging to the same company that supplied the seedlings. The inoculum was kept in ministumps that remained in a temperature-controlled room (23 \pm $2^{\circ} \mathrm{C}$ ) and $12 \mathrm{~h}$ photoperiod. For the inoculation procedure, in the ministumps and in the seedlings that received the treatments, powdery mildew were collected from leaves infected naturally in the clonal mini garden and removed by surface scraping with the aid of a brush, and were inoculated in the upper third of healthy seedlings.

\subsection{Preventive and curative treatments}

Five biological control agents were tested as treatments for preventive and curative control: Predatox ${ }^{\circledR}$ (Trichoderma spp.); Ecotrich ${ }^{\circledR}$ (Trichoderma harzianum); Trichodel aéreo ${ }^{\circledR}$ (Trichoderma harzianum); Nemathel ${ }^{\circledR}$ (Bacillus spp.) and Trichoderma atroviride liquid suspension of conidia. The latter was isolated from Pinus sp. (Lazarotto et al., 2016). For all biocontrol agents, the concentration of $10^{7}$ conidia $\mathrm{mL}^{-1}$ or CFU mL $\mathrm{mL}^{-1}$ was used. Two fungicides were used as positive controls to compare the efficacy of biocontrol agents: Kumulus ${ }^{\circledR}$, (sulfur at $0.3 \mathrm{~g} 100 \mathrm{~mL}^{-1}$ of distilled water); and Score ${ }^{\circledR}$, (difenoconazole at $0.03 \mathrm{~mL} 100$ $\mathrm{mL}^{-1}$ of distilled water), as well as a control treatment using water (Table 1). Preventive treatments were composed of 4 replicates of 6 seedlings for each treatment, while curative treatments were composed of 4 replicates of 10 seedlings for each treatment. Both experiments were designed in a completely randomized design.

The same volume of suspension was used at the concentration of $10^{7}$ conidia or cells $\mathrm{mL}^{-1}$, and one drop of Tween 80 was added. The dilution of each product was determined from the concentration established on the labels, except for the suspension of conidia of $T$. atroviride, which was counted in a Neubauer chamber. For fungicide Score ${ }^{\circledR}$ the recommended dose for rose powdery mildew (Sphaerotheca panossa) of the label of the commercial product was used $(30 \mathrm{~mL}$ $100 \mathrm{~L}^{-1}$ of water), and for fungicide Kumulus ${ }^{\circledR,}$, Alfenas et al. (2009) recommendation for eucalypt powdery mildew (3 $\mathrm{g} \mathrm{L}^{-1}$ of water) was used.

Table 1 - Description of the biological and chemical treatments used for the control of powdery mildew in Eucalyptus benthamii. Porto Alegre, RS, 2016.

Tabela 1 - Descrição dos tratamentos biológicos e químico utilizados para controle do oídio em Eucalyptus benthamii. Porto Alegre, RS, 2016.

\begin{tabular}{|c|c|c|c|}
\hline Treatment & Acronym & Composition & $\begin{array}{c}\text { Commercial } \\
\text { Brand }\end{array}$ \\
\hline \multirow{5}{*}{ Biological } & THP & $\begin{array}{c}\text { Trichoderma } \\
\text { harzianum }\end{array}$ & Predatox $^{\circledR}$ \\
\hline & THE & $\begin{array}{c}\text { Trichoderma } \\
\text { harzianum }\end{array}$ & Ecotrich $^{\circledR}$ \\
\hline & TTA & $\begin{array}{l}\text { Trichoderma } \\
\text { spp.Trichodel }\end{array}$ & aéreo ${ }^{\circledR}$ \\
\hline & TAI & $\begin{array}{c}\text { Trichoderma } \\
\text { atroviride }\end{array}$ & $\begin{array}{c}\text { Collection } \\
\text { isolated }\end{array}$ \\
\hline & $\mathrm{BNE}$ & Bacillus spp. & Nemathel $^{\circledR}$ \\
\hline Chemical & $\begin{array}{l}\text { KUM } \\
\text { SCO }\end{array}$ & $\begin{array}{c}\text { Sulfur } \\
\text { Difenoconazol }\end{array}$ & $\begin{array}{c}\text { Kumulus }^{\circledR} \\
\text { Score }^{\circledR}\end{array}$ \\
\hline Control & $\mathrm{AD}$ & Distilled water & - \\
\hline
\end{tabular}

${ }^{\circledR}$ Trade mark.

The application of preventive and curative treatments was performed by spraying with hand sprayers for each product tested. Treatments were sprayed preventively seven days before pathogen inoculation, in the adaxial and abaxial faces of all leaves until runoff. One week later, the pathogen was inoculated with a brush by scraping conidia present on infected leaves, followed by transferring them to the upper third of the seedlings. The seedlings remained in a growth chamber with a temperature of $23 \pm 2^{\circ} \mathrm{C}$ and $12 \mathrm{~h}$ photoperiod, for 56 days.

The curative treatments followed the same procedure, but were applied 10 days before the inoculation. Treatments were applied in the adaxial and abaxial faces of all the leaves until runoff, and the seedlings remained in greenhouse at ambient temperature conditions for 37 days.

The severity of the disease in eucalypt seedlings was evaluated weekly. The descriptive scale presented in Table 2 was used for severity evaluation. The notes

Revista Árvore. 2018;42(5):e420504 
of this descriptive scale were used to calculate the disease index (DI, ranging from 0 to 1 ), expressed by the equation:Eq. 1

$$
\mathrm{DI}=\frac{\Sigma(\mathrm{Y} * \mathrm{Xy})}{\mathrm{Xt} * \mathrm{~h}}
$$

in which $\mathrm{Y}$ is the note obtained in the scale, $\mathrm{X}_{\mathrm{y}}$ is the number of plants with $\mathrm{Y}$ note, $\mathrm{X}_{\mathrm{t}}$ is the total number of plants and $h$ is the maximum value of the scale (Mckinney, 1923).

Disease incidence was determined by the number of infected seedlings weekly. Severity and incidence values of each treatment were used to calculate the area under the disease progress curve (AUDPC) (Campbell and Madden, 1990), according to the formula below:Eq. 2

$$
{ }_{A U D P C}=\sum\left[\left(\frac{y_{1}+y_{2}}{2}\right) *\left(t_{2}-t_{1}\right)\right]
$$

$\mathrm{y}_{1}$ : evaluation note in time $\mathrm{t}_{1}$

$\mathrm{y}_{2}$ : consecutive evaluation note in time $\mathrm{t}_{2}$

$\mathrm{t}_{2}-\mathrm{t}_{1}$ : interval in days between two consecutive evaluations

For each variable analyzed, the average of the data was calculated and the normality of the data was confirmed. The analysis of variance was performed, and the averages compared by Tukey's test at 5\% probability using SAS 9.4.

\section{RESULTS}

A significant reduction of the DI with the treatments TAI (Trichoderma atroviride) and BNE (Bacillus spp.) was observed with the preventive treatments (Table 3 ). All treatments reduced the incidence of the disease, except TTA for AUDPC (DI), and TTA and THP treatments that were statistically equal for AUDPC (I).

Regarding the Final incidence, evaluated 56 days after inoculation, the control treatment (AD) presented high disease incidence (83.3\%), and was statistically equal to the treatments $\mathrm{SCO}(87.5 \%)$ and TTA $(95.8 \%)$. The treatments with the lowest Final incidence were TAI (29.2\%) (T. atroviride), and BNE (41.7\%) (Bacillus spp.). This demonstrates that even if the fungicide SCO is recommended for the control of other powdery mildew species, it was not effective for the preventive
Table 2 - Descriptive scale used to evaluate the severity of powdery mildew in cuttings of Eucalyptus benthamii. Porto Alegre, RS, 2016.

Tabela 2-Escala descritiva utilizada para avaliar a severidade de oídio em mudas clonais de Eucalyptus benthamii.

\begin{tabular}{|c|c|c|}
\hline Score & $\begin{array}{l}\text { Description of } \\
\text { disease severity }\end{array}$ & Visual symptoms \\
\hline $\mathbf{0}$ & No symptoms & Absent \\
\hline 1 & Low infection & $\begin{array}{l}\text { Presence of mycelium of } \\
\text { the fungus on the leaves, } \\
\text { without sporulation }\end{array}$ \\
\hline 2 & Medium infection & $\begin{array}{c}\text { Sporulation on the first } \\
\text { pairs of leaves }\end{array}$ \\
\hline 3 & High infection & $\begin{array}{l}\text { Deformation, shrouding } \\
\text { and leaf fall }\end{array}$ \\
\hline
\end{tabular}
Porto Alegre, RS, 2016.

Table 3 - Evaluation of the final McKinney Disease Index (final DI), Final Incidence (Final I) and Area Under the Disease Progress Curve (AUDPC) of DI and I, data in percentage (\%) of preventive treatments applied by foliar spray in cuttings of Eucalyptus benthamii for the control of Oidium eucalypti. Porto Alegre, RS, 2016.

Tabela 3 - Avaliação do Índice de Doença de McKinney final (DI final), da Incidência final (Ifinal) e das Areas Abaixo da Curva de Progresso da Doença (AUDPC) de DI I, valores em porcentagem (\%) dos tratamentos preventivos aplicados via foliar em mudas clonais de Eucalyptus benthamii para o controle de Oidium eucalypti. Porto Alegre, RS, 2016.

\begin{tabular}{ccccr}
\hline Treatment & $\begin{array}{c}\text { DI } \\
\text { final }\end{array}$ & $\begin{array}{c}\text { AUDPC } \\
(\mathrm{DI})\end{array}$ & $\begin{array}{c}\text { AUDPC } \\
(\mathrm{I})\end{array}$ & $\begin{array}{c}\text { I } \\
\text { final }\end{array}$ \\
\hline AD & $49.2 \mathrm{~A}$ & $694.7 \mathrm{AB}^{*}$ & $1560.4 \mathrm{~A}$ & $83.3 \mathrm{~A}$ \\
$\mathrm{KUM}$ & $45.5 \mathrm{~A}$ & $566.8 \mathrm{ABC}$ & $1137.5 \mathrm{AB}$ & $66.7 \mathrm{AB}$ \\
SCO & $51.4 \mathrm{~A}$ & $422.9 \mathrm{BCD}$ & $918.8 \mathrm{ABC}$ & $87.5 \mathrm{~A}$ \\
$\mathrm{THP}$ & $46.4 \mathrm{~A}$ & $771.5 \mathrm{AB}$ & $1647.9 \mathrm{~A}$ & $70.8 \mathrm{AB}$ \\
THE & $44.4 \mathrm{~A}$ & $481.3 \mathrm{ABCD}$ & $1108.3 \mathrm{ABC}$ & $75.0 \mathrm{AB}$ \\
$\mathrm{BNE}$ & $24.0 \mathrm{~B}$ & $278.5 \mathrm{CD}$ & $612.5 \mathrm{BC}$ & $41.7 \mathrm{BC}$ \\
TTA & $53.6 \mathrm{~A}$ & $800.1 \mathrm{~A}$ & $1677.1 \mathrm{~A}$ & $95.8 \mathrm{~A}$ \\
TAI & $12.2 \mathrm{~B}$ & $126.4 \mathrm{D}$ & $335.4 \mathrm{C}$ & $29.2 \mathrm{C}$ \\
\hline p Value & $<$ & & & $<0.000$ \\
& 0.0001 & $<0.0001$ & $<0,0001$ & 1 \\
\hline
\end{tabular}

*Averages followed by the same letter in the columns are not different by Tukey's test at $5 \%$ significance. AD: Control; KUM: fungicide

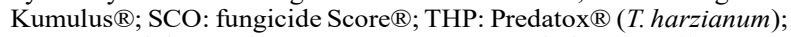
THE: Ecotrich ${ }^{\circledR}$ (T. harzianum); BNE: Nemathel ${ }^{\circledR}$ (Bacillus spp.); TTA: Trichodel Aéreo ${ }^{\circledR}$ (Trichoderma spp.); TAI: T. atroviride.

control of eucalypt powdery mildew. However, KUM, at the recommended dose in the literature for the control eucalypt powdery mildew, reduced disease incidence in relation to the control. Nonetheless, it was less effective than the previously mentioned biological treatments.

Revista Árvore. 2018;42(5):e420504 
The TTA treatment (Trichoderma spp.) obtained the highest AUDPC values (800.1\% and 1677.1\%) for disease severity and incidence $(53.6 \%$ and $95.8 \%$, respectively), with no significant difference compared to the others Trichoderma biological preventive treatments, except TAI (Trichoderma atroviride). This show that probably then could have different effects on the action and effectiveness of biological agents even if they are antagonists of the same genus. The lowest values of AUDPC, severity and incidence, observed in the TAI treatment (Trichoderma atroviride), confirm its efficiency in the control of eucalypt powdery mildew, when used preventively (Table 3 ).

Curative treatments to control Oidium eucalypti showed that BNE (Bacillus spp.) had greater efficiency (Table 4). This treatment showed the lowest values of AUDPC for severity (394.2\%) and incidence (798.8\%). For this last variable, it was statistically equal to the chemical treatment KUM. In addition, it presented lower final incidence of disease (10\%) differing significantly from the control and THP, TTA and TAI treatments

Table 4 - Evaluation of the final McKinney Disease Index (final DI), Final Incidence (Final I), and Area Under the Disease Progress Curve (AUDPC) of DI and I, data in percentage $(\%)$ of curative treatments applied by foliar spray in cuttings of Eucalyptus benthamii for the control of Oidium eucalypti. Porto Alegre, RS, 2015.

Tabela 4 - Avaliação do Índice de Doença de McKinney final (DI final), da Incidência final (I final) e das Areas Abaixo da Curva de Progresso da Doença (AUDPC) de DI e I, valores em porcentagem (\%), dos tratamentos curativos aplicados via foliar em mudas clonais de Eucalyptus benthamii para o controle de Oidium eucalypti. Porto Alegre, RS, 2015.

\begin{tabular}{ccccc}
\hline Tratamento & $\begin{array}{c}\text { DI } \\
\text { final }\end{array}$ & $\begin{array}{c}\text { AUDPC } \\
(\mathrm{DI})\end{array}$ & $\begin{array}{c}\text { AUDPC } \\
(\mathrm{I})\end{array}$ & $\begin{array}{c}\text { I } \\
\text { final }\end{array}$ \\
\hline AD & $19.2 \mathrm{~ns}$ & $789.6^{*} \mathrm{AB}$ & $1743.8 \mathrm{AB}$ & $52.5 \mathrm{~A}$ \\
SCO & 16.7 & $685.0 \mathrm{AB}$ & $1355.0 \mathrm{ABC}$ & $30.0 \mathrm{ABC}$ \\
KUM & 12.5 & $512.1 \mathrm{AB}$ & $913.8 \mathrm{C}$ & $17.5 \mathrm{BC}$ \\
THP & 20.8 & $790.4 \mathrm{AB}$ & $1981.3 \mathrm{AB}$ & $57.5 \mathrm{~A}$ \\
THE & 16.7 & $654.6 \mathrm{AB}$ & $1300.0 \mathrm{BC}$ & $35.0 \mathrm{ABC}$ \\
BNE & 6.7 & $394.2 \mathrm{~B}$ & $798.8 \mathrm{C}$ & $10.0 \mathrm{C}$ \\
TTA & 18.3 & $846.3 \mathrm{AB}$ & $1953.8 \mathrm{AB}$ & $45.0 \mathrm{AB}$ \\
TAI & 24.2 & $966.3 \mathrm{~A}$ & $2011.3 \mathrm{~A}$ & $52.5 \mathrm{~A}$ \\
\hline p Valor & 0.1774 & 0.0228 & $<0.0001$ & $<0.0002$ \\
\hline
\end{tabular}

* Averages followed by the same letter in the columns are not different by Tukey's test at $5 \%$ significance. AD: Control; KUM: fungicide Kumulus ${ }^{\circledR}$; SCO: fungicide Score ${ }^{\circledR}$; THP: Predatox ${ }^{\circledR}$ (T. harzianum); THE: Ecotrich ${ }^{\circledR}$ (T. harzianum); BNE: Nemathel ${ }^{\circledR}$ (Bacillus spp.); TTA: Trichodel Aéreo ${ }^{\circledR}$ (Trichoderma spp.); TAI: T. atroviride.
(Table 4). It is highlighted here difference in the behavior of TAI (Trichoderma atroviride), since this treatment (TAI) was similar in terms of efficiency with BNE in a preventive way, which was not observed in the curative treatments.

Fungicide treatments, SCO and KUM, also reduced the incidence and, or, severity of powdery mildew in eucalypt seedlings, although, they did not present a significant difference compared to the biological treatments.

\section{DISCUSSION}

The significant preventive and curative effects of the biological treatments TAI and BNE applied to the control of Oidium eucalypti make it possible to establish alternatives for the control of this pathogen in Eucalyptus benthamii seedlings. The efficiency of BNE (Bacillus spp.) in preventive and curative control of eucalypt powdery mildew may be associated to the antimicrobial production, such as lipopeptides, which may be of three types: fengicins, iturin and surfacins (Ongena and Jacques, 2008) and several substances that inhibit other microorganisms (Bettiol et al., 2005).

Bacillus subtilis acts directly or indirectly in the control of plant diseases (Ongena et al., 2007; Leelasuphakul et al., 2008). The direct antagonism exerted against phytopathogens occurs through antibiosis, synthesis of antimicrobial substances, parasitism, competition for space and nutrients, and the synthesis of volatile compounds (Leelasuphakul et al., 2008). This may explain the action of BNE in the preventive control of eucalypt powdery mildew. Bacillus species have the ability to produce endospores that are resistant to high temperatures and survive in adverse environmental conditions (Collins and Jacobsen, 2003), favoring their action as agents of biological control. According to Kupper et al. (2003), generally, microorganisms that act by antibiosis have broad spectrum of action, so that the production of toxic substances is more effective than any other mechanism of action involved in the inhibition of fungi.

For eucalypt species, the reduction in disease incidence caused by Puccinia psidii in two hybrids of E. urophylla and E. grandis was significant for one of the clones using treatments with inoculation of Rizolyptus ${ }^{\circledR}$ (Bacillus subtilis) in minicuttings and in the substrate with reduction of 28.1 and $40.1 \%$ of 
the disease compared to the control treatment. Reduction of disease severity was obtained for the two clones, by $45.9 \%$ for one clone and from 65.7 to $70.9 \%$ for the other one (Raasch et al., 2012).

A study by Romero et al. (2004) reported four strains of Bacillus subtilis as potential biocontrol agents against powdery mildew caused by Podosphaera fusca, a pathogen of cucurbitaceae. The relevant role of iturins and fengicins in the antifungal activity and in the control of the cucurbit powdery mildew has been demonstrated (Romero et al., 2007b). In addition, these strains controlled powdery mildew under greenhouse conditions and demonstrated their fermentation potential for largescale production (Romero et al., 2007a). According to Ashwini and Srividya (2014), Bacillus subtilis not only produces antibiotics but also produces different types of enzymes such as glucanase, chitinase, and cellulase, which also play a very important role in the antagonistic property through the mechanism mediated by lytic enzymes.

The forms of action of antagonistic microorganisms could be attributed to the different mechanisms of action regarding biocontrol agents. Trichoderma species are capable of acting through competition for space and nutrients, production of volatile antibiotics and hydrolytic enzymes such as chitinase and â-1,3-glucanase (Chutrakul et al., 2008; Sharma et al., 2009). Hydrolytic enzymes partially degrade the cell wall of the pathogen and lead to parasitism (Kubicek et al., 2001). There may also be a direct interaction between the pathogen itself and the biocontrol agent, in the case of mycoparasitism, which involves physical contact and synthesis of hydrolytic enzymes, toxic compounds and, or, antibiotics that act synergistically with the enzymes. Fungi of the genus Trichoderma can even exert positive effects on plants, with an increase in their growth, in the case of application by biofertilization, and also by stimulating plant defense mechanisms (Benitéz et al., 2004).

Biological control agents are living organisms and their activities depend mainly on the different physicochemical conditions that are subjected. The understanding of Trichoderma intraspecific genetic diversity and its biocontrol mechanisms result in better implementation of the selected isolates as biocontrol agents (Benitéz et al., 2004). Also, the use of Trichoderma spp., isolated in vitro and in vivo, is considered an excellent biocontrol agents and has the advantage of being less harmfull to humans (Melo, 1996) and does not cause negative impacts on the environment (Patrício et al., 2001), contrasting with the toxic action caused by chemical fungicides. These studies reiterate the results obtained with the present study in which the treatment TAI (T. atroviride) showed a greater efficiency in the control of eucalypt powdery mildew when preventively applied.

Although the biological treatments THE, TTA, TAI, THP and the chemical fungicide SCO did not show significant differences from the control, the former are still more advantageous, since these microorganisms can promote plant growth, as already evidenced in several studies (Amaral et al., 2017; Chagas et al., 2017; Gonçalves et al., 2018). Carvalho Filho et al. (2008) concluded that the isolate CEN 262 of Trichoderma spp. provided greater index of development of shoots in eucalypt seedlings. Some strains of Trichoderma have the ability to endophytically colonize different organs of the plant (Rubini et al., 2005; Silva et al., 2006). In addition to controlling disease, it would be possible to increase the production of minicuttings in clonal eucalypt mini gardens, an effect that does not occur with the use of chemical fungicides.

All the biological treatments applied both preventively and curatively, reduced AUDPC. A study by Belan et al. (2013) using alternative treatments for cucumber (Cumumis sativus L.) powdery mildew control, observed that the treatment with distilled water used as negative control obtained the lowest reduction of the fungus population, except when compared to the alcoholic extract of propolis treatment.

Several studies point out that chemicals are not as effective in controlling diseases caused by Oidium eucalypti. Picinini et al. (2003) using different fungicides for the treatment of wheat seeds, observed that difenoconazole, applied at the dose of $30 \mathrm{~g}$ a.i $100 \mathrm{~kg}^{-}$ ${ }^{1}$ seeds showed greater severity of powdery mildew (Blumeria graminis f. sp. tritici) at 60 days after plant emergence when compared to another active principle, such as fluquinconazole. This demonstrates that a chemical fungicide based on difenoconazole is not efficient in the control of Oidium eucalypti and other species of the fungus. As for Pavanello et al. (2015), the fungicide difenoconazole controlled brown rot, caused by the fungus Monilinia fructicola, until harvest, presenting a $0.84 \%$ of rot incidence caused by the fungus, whereas the control presented $10.2 \%$.

Revista Árvore. 2018;42(5):e420504 
The results of the present study suggest that it is possible to opt for the use of preventive and curative treatments based on biological antagonists rather than a chemical treatment, which may favor the increase of disease incidence during growth of seedlings. Biological treatments by spraying biological control agents could be considered a viable alternative for the control of powdery mildew, such as Oidium eucalypti in replacement for the chemical fungicides that cause genetic resistance to pathogens due to their frequent use in the combat against a certain microorganisms, besides leading to residual harmful effects for workers' health and to the environment.

\section{CONCLUSIONS}

Biological treatments with Trichoderma atroviride and Bacillus spp. can be applied preventively, and the treatment based on Bacillus spp. can be applied after the appearance of disease symptoms to control Oidium eucalypti in cuttings of Eucalyptus benthamii under controlled environment and greenhouse conditions.

\section{ACKNOWLEDGEMENTS}

The authors thank the Coordenação de Aperfeiçoamento de Pessoal de Nível Superior (CAPES) for granting a master's degree scholarship for the first author and the Company CMPC - Celulose Riograndense, for the donation of the minicuttings of Eucalyptus spp. and for helping to carry out this research.

\section{REFERENCES}

Alfenas AC, Zauza EAV, Mafia RG, Assis TF. Clonagem e doenças do eucalipto. $2^{\mathrm{a}}$ ed. Viçosa, MG: Editora UFV; 2009.

Amaral PP, Steffen GPK, Maldaner J, Missio EL, Saldanha CW Promotores de crescimento na propagação de caroba. Pesquisa Florestal Brasileira. 2017;37:149-57

Angonese MT, Della-Giustina J, Paim LH, Pansera MR, Pagno RS, Mezzomo F, et al. Fungistatic effect of Bacillus spp. on plant pathogenic fungi. Revista Brasileira de Agroecologia. 2009;4:97-100.

Ashwini N, Srividya S. Potentiality of Bacillus subtilis as biocontrol agent for management of anthracnose disease of chilli caused by Colletotrichum gloeosporioides OGC1. 3 Biotech 2014;4:127-136.
Bacon CW, Yates IE, Hinton DM, Meredith F. Biological control of Fusarium moniliforme in maize. Environmental Health Perspectives. 2001;109:325-32.

Belan LL, Pereira AJ, Oliveira MJV, Barbosa DHSG, Jesus Junior WC, Alves FR. Manejo alternativo do oídio na cultura do pepino em ambiente protegido. Revista Acadêmica Ciências Agrárias e Ambientais. 2013;11:S103-S112.

Benitéz T, Ricón AM, Limón MC, Códon AC Biocontrol mechanisms of Trichoderma strains. International Microbiology. 2004;7:249-60.

Bettiol W, Ghini R, Morandi MAB. Alguns métodos alternativos para o controle de doenças de plantas disponíveis no Brasil. In: Venzon M, Paula Júnior TJ, Pallini A, editores. Controle alternativo de pragas e doenças. Viçosa, MG: EPAMIG/CTZM; 2005. p.163-83.

Bettiol W, Morandi MAB. Biocontrole de doenças de plantas: uso e perspectivas. Jaguariúna: Embrapa Meio Ambiente; 2009.

Brotman Y, Gupta, KJ, Viterbo A. Trichoderma. Current Biology. 2010;20:R390 R391.

Campbell CL, Madden LV. Introduction to plant disease epidemiology. New York: WileyInterscience; 1990.

Campanhola C, Bettiol W. Métodos alternativos de controle fitossanitário. Jaguariúna: Embrapa Meio Ambiente; 2003.

Carvalho Filho MR, Mello SCM, Santos RP, Menêzes JE. Avaliação de isolados de Trichoderma na promoção de crescimento, produção de ácido indolacético in vitro e colonização endofítica de mudas de eucalipto. Embrapa Recursos Genéticos e Biotecnologia; 2008. (Boletim de Pesquisa e Desenvolvimento, 226).

Carvalho DCD, Mello SCM, Lobo Júnior M, Silva MC. Controle de Fusarium oxysporum f.sp. phaseoli in vitro e em sementes, e promoção do crescimento inicial do feijoeiro comum por Trichoderma harzianum. Tropical Plant Pathology. 2011;36:28-34.

Chagas LFB, Chagas Junior AF, Soares LP, Fidelis RR. Trichoderma na promoção do crescimento

Revista Árvore. 2018;42(5):e420504 
vegetal. Revista de Agricultura Neotropical. 2017;4:97-102.

Chutrakul C, Alcocer M, Bailey K, Peberdy JF. The production and characterization of Trichotoxin peptaibols by Trichoderma asperellum. Chemistry and Biodiversity. 2008;5:1694-706.

Collins C, Jacobsen BJ. Optimizing a Bacillus subtilis isolate for biological control of sugar beet cercospora leaf spot. Biological Control. 2003;26:153-61.

Dong YH, Zhang XF, Xu JL, Zhang LH. Insecticidal Bacillus thuringiensis silences Erwinia carotovora virulence by a new form of microbial antagonism, signal interference. Applied and environmental microbiology. 2004;70:954-60.

Gonçalves AH, Chagas LFB, Santos GR, Fidelis RR, C Filho MR, Miller LO, Chagas Junior AF Trichoderma efficiency in the maintenance and productivity of soybean plants in producing savanna regions, Tocantins, Brazil. Revista de Ciência Agrárias. 2018;41:175-81.

Hang NTT, Oh SO, Kim GH, Hur JS, Koh YJ. Bacillus subtilis S1-0210 as a biocontrol agent against Botrytis cinerea in strawberries. The Plant Patology Journal. 2005;21:59-63.

Harmam GE, Howell CR, Viterbo A, Chet I, Lorito M. Trichoderma species opportunistic, avirulent plant symbionts. Nature Reviews Microbiology. 2004;2:43-56.

Indústria Brasileira de Árvores - IBÁ. Relatório Anual 2017. [acessado em: 01. out. 2018] https:// iba.org/datafiles/publicacoes/pdf/ibarelatorioanual2017.pdf.

Krugner TL, Auer CG. Doenças do eucalipto. In: Kimati H, Amorim L, Bergamin Filho A., Camargo LEA, Rezende JAM, editores. Manual de fitopatologia: doenças das plantas cultivadas. 4th ed. São Paulo: Agronômica Ceres; 2005.

Kubicek CP, Mach RL, Peterbauer CK, Lorito M. Trichoderma: From genes to biocontrol. Journal of Plant Pathology. 2001;83:11-23.

Kupper KC, Gimenes-Fernandes N, Goes A. Controle biológico de Colletotrichum acutatum, agente causal da queda prematura dos frutos cítricos. Fitopatologia Brasileira. 2003;28:251-7.

Lazarotto M, Oliveira LS, Harakava R, Zanatta P, Farias CRJ. Identificação de fungos emboloradores em madeira de Pinus spp. em laboratório. Floresta e Ambiente. 2016;23:602-5.

Mckinney HH. Influence of soil, temperature and moisture on infection of wheat seedlings by Helminthosporium sativum. Journal of Agricultural Researc. 1923;26:195-217.

Leelasuphakul W, Hemmanee P, Chuenchitt S. Growth inhibitory properties of Bacillus subtilis strains and their metabolites against the green mold pathogen (Penicillium digitatum Sacc.) of citrus fruit. Postharvest Biology and Technology. 2008;48:113-21.

Melo IS. Trichoderma e Gliocladium como bioprotetores de plantas. Revisão Anual de Patógenos de Plantas. 1996;4:261-95.

Montero MB, Hermosa R, Cardoza RE, Gutiérrez $\mathrm{S}$, Monte E. Functional analysis of the Trichoderma harzianum nox 1 gene, encoding an NADPH oxidase, relates production of reactive oxygen species to specific biocontrol activity against Pythium ultimum. Applied and Environmental Microbiology. 2011;77:3009-16.

Ongena M, Jacques P. Bacillus lipopeptides: Versatile weapons for plant disease control. Trends in Microbiology. 2008;16:115-25.

Ongena M, Jourdan E, Adam A, Paquot M, Brans A, Joris B, Arpigny JL, Thonart P. Surfactin and fengycin lipopeptides of Bacillus subtilis as elicitors of induced systemic resistance in plants. Environmental Microbiology . 2007;9:1084-1090.

Pavanello EP, Brackmann A, Thewes FR, Both V, Santos JRA, Schorr MRW. Eficiência de fungicidas no controle da podridão parda do pessegueiro e sua relação com parâmetros fisiológicos dos frutos. Semina: Ciências Agrárias 2015;36:67-76.

Patrício FRA, Kimati H, Barros BC. Seleção de isolados de Trichoderma spp. antagônicos a Pythium aphanidermatum e Rhizoctonia solani.

Revista Árvore. 2018;42(5):e420504 
Summa Phytopathologica. 2001;27:223-9.

Picinini EC, Fernandes JMC. Efeito do tratamento de sementes com fungicida sobre o controle de doenças na parte aérea do trigo. Fitopatologia Brasileira. 2003;28:515-20.

Raasch LD, Bonaldo SM, Oliveira AAF. Rizolyptus ${ }^{\circledR}$ na proteção de miniestacas de eucalipto contra Puccinia psidii. Enciclopédia Biosfera. 2012;8:854-64.

Romero D, Pérez-García A, Rivera ME, Cazorla FM, De Vicente A. Isolation and evaluation of antagonistic bacteria towards the cucurbit powdery mildew fungus Podosphaera fusca. Applied Microbiology Biotechnology. 2004;64:263-9.

Romero D, De Vicente A, Rakotoaly RH, Dufour SE, Veening JW, Arrebola E, et al. The iturin and fengycin families of lipopeptides are key factors in antagonism of Bacillus subtilis toward Podosphaera fusca. Molecular Plant-Microbe Interactions. 2007b;20:430-40.

Romero D, De Vicente AD, Zeriouh H, Cazorla FM, Fernández-Ortuño D, Torés JA, et al. Evaluation of biological control agents for managing cucurbit powdery mildew on greenhouse-grown melon. Plant Pathology. 2007a;56:976-86.

Rubini MR, Silva-Ribeiro RT, Pomella AWV, Maki CS, Araújo WL, Santos DR, et al. Diversity of endophytic fungal community of cacao (Theobroma cacao L.) and biological control of Crinipellis perniciosa, causal agent of Witches' Broom Disease. International Journaul Biology Science. 2005;1:24-33.

Ruocco M, Lanzuise S, Vinale F, Marra R, Turrà D, Woo SL, et al. Identification of a new biocontrol gene in Trichoderma atroviride: the role of an ABC transporter membrane pump in the interaction with different plant-pathogenic Fungi. Molecular Plant Microbe Interactions. 2009;22:291-301.
Santos AF, Auer CG, Grigoletti Júnior A. Doenças do eucalipto no sul do Brasil: identificação e controle. Colombo: Embrapa Florestas; 2001.

Sanz L, Montero M, Redondo J, Llobell A, Monte E. Expression of an a-1,3-glucanase during mycoparasitic interaction of Trichoderma asperellum. The FEBS Journal. 2005;272:493-9.

Schultz B. Levantamento de doenças bióticas e abióticas em Eucalyptus benthamii Maiden nos estados do Paraná e Santa Catarina [dissertação] Curitiba: Universidade Federal do Paraná; 2011.

Silva RLO, Luz JS, Silveira EB, Cavalcante UMT. Fungos endofíticos em Annona spp.: isolamento, caracterização enzimática e promoção de crescimento em mudas de pinha. Acta Botânica Brasileira. 2006;23:649-55.

Sharma K, Kumar M, Misra RM. Morphological, biochemical and molecular characterization of Trichoderma harzianum isolates for their efficacy as biocontrol agents. Journal of Phytopathology. 2009;157:51-6.

Shoresh M, Yedidia I, Chet I. Involvement of jasmonic acid/ethylene signaling pathway in the systemic resistance induced in cucumber by Trichoderma asperellum T203. Phytopathology. 2005;95:76 84 .

Simões MLG. Evaluation of Trichoderma spp. for the Biocontrol of Moniliophthora perniciosa Subgroup 1441. Journal of Biology and Life Science. 2012;3:18-36.

Vinale F, Sivasithamparam K, Ghisalberti EL, Marra $\mathrm{R}$, Barbetti MJ, Li H, et al. A novel role for Trichoderma secondary metabolites in the interactions with plants. Physiological and Molecular Plant Pathology. 2008;72:80 6.

Viterbo A, Harel M, Horwitz BA, Chet I, Mukherjee PK. Trichoderma mitogen activated protein kinase signaling is involved in induction of plant systemic resistance. Applied and Environmental Microbiology. 2005;71:6241 6. 